\title{
PENYAKIT BERCAK DAUN PADA SEMAI NYATOH (Palaquium sp.) DI PERSEMAIAN BALAI PENELITIAN KEHUTANAN CIAMIS
}

\author{
Leaf Spot Disease on Nyatoh (Palaquium sp.) Seedlings in the Nursery \\ of Ciamis Forestry Research Institute
}

\author{
Illa Anggraeni ${ }^{1)}$ dan/and Benyamin Dendang ${ }^{2)}$ \\ ${ }^{1)}$ Pusat Penelitian dan Pengembangan Hutan Tanaman \\ Kampus Balitbang Kehutanan, Jl. Gunung Batu No. 5, Bogor \\ Telp. (025) 8631238, Fax. (0251) 7520005 \\ ${ }^{2)}$ Balai Penelitian Kehutanan Ciamis \\ J1. Raya Ciamis-Banjar KM. 4 Desa Pamalayan, Ciamis 46201 \\ Telp. (0265) 771352, Fax. (0265) 715866
}

Naskah masuk : 8 Juli 2008 ; Naskah diterima : 19 Januari 2009

\begin{abstract}
Seedlings of nyatoh (Palaquium sp.) in nursery of Pamalayan Village, Ciamis have been attacked by leaf spot disease. Symptom of the disease is common on each plant attacked, which is the appearance of dead area of leaf (necrocis). Initial symptom is shown by brownish circular spots with yellow edges, and in relatively short time the spots expanded and changed the color into blackish red. Spots on leaf surface are started from leaf side toward the center. If the attacked leaf is touched, the leaf will easily fall, or the leaf will slowly dry and fall. The study had objective to identify the pathogen of the disease. Information gained is important as the initial process to take necessary control of the disease. The result of Koch Postulate test and identification showed that pathogen of the nyatoh seedlings disease was Colletotrichum $s p$. Average percentage of leaf spot occurance was $96 \%$ on Plot I, 96\% on Plot II and 100\% on Plot III. Meanwhile average intensity of the disease was $24,6 \%$ on Plot I, 28,8\% on Plot II and $31,45 \%$ on Plot III.
\end{abstract}

\section{Keywords: Colletotrichum sp., Nyatoh (Palaquium sp.), leaf spot disease}

\begin{abstract}
ABSTRAK
Bibit nyatoh (Palaquium sp.) di persemaian Desa Pamalayan, Ciamis terserang penyakit bercak daun. Ciri dan gejala penyakit bercak daun pada umumnya sama pada setiap tanaman yaitu terbentuknya daerah yang mati pada daun (nekrosis). Bercak berwarna coklat dengan tepi agak kekuning-kuningan dan kemudian berubah menjadi merah kehitam-hitaman. Letak bercak pada permukaan daun dimulai dari tepi menuju ke bagian tengah daun. Apabila daun yang terserang disentuh, maka daun tersebut gugur, apabila dibiarkan lama kelamaan daun menjadi kering dan rontok. Penelitian ini bertujuan untuk mengetahui jenis patogen penyebab penyakit, informasi yang diperoleh merupakan proses awal untuk mengambil tindakan pengendalian penyakit. Dari hasil uji "Postulat Koch" dan identifikasi, ternyata penyebab penyakit bercak daun bibit nyatoh adalah fungi Colletotrichum sp. Persentase rata-rata kejadian penyakit bercak daun pada bibit nyatoh pada plot pengarnatan I sebesar $96 \%$, plot I I sebesar $96 \%$ dan plot III mencapai $100 \%$. Sedangkan rata-rata intensitas serangan penyakit pada plot pengamatan I sebesar $24,60 \%$, plot II sebesar $28,87 \%$ dan plot III sebesar $31,45 \%$.
\end{abstract}

Kata kunci : Colletotrichum sp., Nyatoh (Palaquium sp.), penyakit bercak daun 


\section{PENDAIIULUAN}

Nyatoh (Palaquium spp.) merupakan salah satu kelompok jenis pohon kayu yang mempunyai nama daerah balam, balem, bengku, ketiau, mayang, nyatoh, punti, sau payo, semaram, suntai (Sumatera), getah perca, jengkot, kawang, kibangkong, kisawo, tanjungan (Jawa), baringin, gata-gata, getah merah, hangkang, katiau, mergetahan, nyatu (Kalimantan), kuma, kume, nantu, nato, sodu-sodu (Sulawesi), arupa, gofiri, nantu, siki, soko, tofiri (Maluku), maneo dan koaaf (Nusa Tenggara) (Martawijaya dkk., 2005). Di Indonesia jenis ini banyak dijumpai di Sumatera, Kalimantan, Jawa, Maluku dan Nusa Tenggara (Balai Teknologi Reboisasi Benakat, 1991).

Kayu nyatoh umumnya baik untuk papan perumahan, bahkan beberapa jenis di antaranya dapat dipakai untuk tiang, balok dan rusuk. P. burkcii, P. obtusifolium dan P. rostratum dapat dipakai untuk membuat perahu atau kano. $P$. rostratum dapat juga dipakai untuk papan lantai, panel, dinding pemisah dan alat rumah tangga, sedangkan kayu banirnya biasa dipakai untuk dayung, roda gerobak, tangkai cangkul dan tangkai kapak. Jenis $P$. javense biasa dipakai untuk membuat gamelan dan mebel halus, khususnya di Jawa Tengah. Keawetan kayu nyatoh secara umum termasuk kelas awet III - IV kecuali P. obtusifolium yang termasuk kelas awet IV - V. Daya tahan kayu $P$. gutta terhadap rayap kayu kering Cryptotermes cynocephalus termasuk kelas V (Martawijaya dkk., 2005).

Salah satu permasalahan yang sangat mengganggu pertumbuhan bibit nyatoh di persemaian Balai Penelitian Kehutanan (BPK) Ciamis adalah adanya serangan penyakit bercak daun. Penyakit ini menimbulkan busuk kebasahan pada daun yang mengakibatkan daun gugur. Serangan berat dapat mengakibatkan gundulnya bibit dan terhambatnya pertumbuhan, pada bibit yang peka dapat menimbulkan kematian. Untuk mengantisipasi serangan lebih lanjut dan untuk mengambil tindakan pengendalian, maka perlu diketahui jenis patogen bercak daun pada bibit nyatoh. Tujuan penelitian ini adalah untuk mengetahui jenis patogen yang menyebabkan penyakit bercak daun pada bibit nyatoh serta ekobiologinya.

\section{BAHAN DAN METODE}

\section{A. Lokasi Penelitian}

Penelitian dilaksanakan di persemaian BPK Ciamis, di Desa Pamalayan. Areal tersebut termasuk ke dalam wilayah pemerintahan Kecamatan Cijeunjing, Kabupaten Ciamis, Propinsi Jawa Barat. Lokasi ini mempunyai ketinggian tempat 110 meter di atas permukaan laut, dengan tipe iklim B (Schmidt \& Ferguson, 1951), rata-rata curah hujan $2.169 \mathrm{~mm} / \mathrm{th}$. Setelah penelitian di lapangan dilanjutkan penelitian di Laboratorium Penyakit, Kelompok Peneliti Perlindungan Hutan, Pusat Penelitian dan Pengembangan Hutan Tanaman, Bogor.

\section{B. Bahan dan Alat}

Bahan penelitian yang digunakan terdiri dari bibit nyatoh umur 4 bulan (sumber benih berasal dari Tana Toraja, Propinsi Sulawesi Selatan), media agar kentang (PDA/Potato Dextrose Agar), alkohol $70 \%$, akuades steril, kapas, kertas saring, kertas hisap, kertas tissue, kertas koran, aluminium foil dan kertas label.

Alat-alat yang digunakan adalah alat pemotong (gunting, silet, pisau/cutter), kaca pembesar (loupe), pinset, jarum ose, gelas obyek, gelas penutup, tabung reaksi, labu Erlenmeyer, lampu Bunsen, cawan petri, oven, otoklaf, foto-mikroskop, ruang isolasi (LAF = Laminary Air Flow) dan kamera. 


\section{Metode}

Penelitian dilakukan dengan menggunakan dua tahapan metode, yaitu pengamatan di lapangan (persemaian) dan di laboratorium.

\section{Di lapangan}

Data yang diambil di lapangan adalah data primer. Data primer diperoleh dari pengamatan langsung di persemaian mengenai gejala penyakit, persentase kejadian penyakit dan intensitas penyakit. Pengamatan tersebut dilakukan dalam plot pengamatan yang terdiri dari tiga plot, masing-masing plot terdiri dari 25 bibit. Persentase kejadian penyakit pada setiap plot pengamatan dihitung dengan rumus :

$\mathrm{P}=\frac{\mathrm{n}}{\mathrm{N}} \mathrm{X} 100 \%$

$\mathrm{P}=$ persentase kejadian penyakit

$\mathrm{n}=$ jumlah bibit yang terserang penyakit dalam plot pengamatan

$\mathrm{N}=$ jumlah seluruh bibit dalam plot pengamatan

Intensitas serangan penyakit pada setiap bibit dalam plot pengamatan dihitung dengan rumus:

$$
\begin{aligned}
& \text { IP }=\frac{\sum n_{\mathrm{i}} \mathrm{V}_{\mathrm{i}}}{\mathrm{NV}} \times 100 \% \\
& \mathrm{IP}=\text { intensitas serangan penyakit } \\
& \mathrm{n}_{\mathrm{i}}=\text { jumlah daun dengan skor ke- } \mathrm{i} \\
& \mathrm{V}_{\mathrm{i}}=\text { nilai skor penyakit dari } 0,1,2,3 \text { dan } 4 \\
& \mathrm{~N}=\text { jumlah daun yang diamati } \\
& \mathrm{V}=\text { skor tertinggi }
\end{aligned}
$$

Daun yang terserang bercak daun dibagi dalam lima kategori (nilai skor) Tabel 1.

Tabel (Table) 1. Katagori serangan penyakit(Attack disease category).

\begin{tabular}{|c|l|l|}
\hline $\begin{array}{c}\text { Nilai Skor } \\
\text { Score rate })\end{array}$ & \multicolumn{1}{|c|}{ Deskripsi serangan (Attack description) } & \multicolumn{1}{|c|}{ Keterangan (Note) } \\
\hline 0 & tidak terserang penyakit (sehat/healthy) $(0)$ & pada daun tidak terdapat bercak \\
\hline 1 & serangan ringan/low attack $(1<\mathrm{x}=25 \%)$ & $\begin{array}{l}\text { pada daun terdapat bercak seluas } \\
(1<\mathrm{x}=25 \%) \text { dari luas daun total }\end{array}$ \\
\hline 2 & $\begin{array}{l}\text { serangan sedang/medium attack } \\
(25 \%<\mathrm{x}=50 \%)\end{array}$ & $\begin{array}{l}\text { pada daun terdapat bercak seluas } \\
(25 \%<\mathrm{x}=50 \%) \text { dari luas daun total }\end{array}$ \\
\hline 3 & serangan berat/heavy attack $(50 \%<\mathrm{x}=75 \%)$ & $\begin{array}{l}\text { pada daun terdapat bercak seluas } \\
(50 \%<\mathrm{x}=75 \%) \text { dari luas daun total }\end{array}$ \\
\hline 4 & $\begin{array}{l}\text { serangan sangat berat sampai gugur/very heavy } \\
\text { attack }(75 \%<\mathrm{x}=100 \%)\end{array}$ & $\begin{array}{l}\text { pada daun terdapat bercak seluas } \\
(75 \%<\mathrm{x}=100 \%) \text { dari luas } \\
\text { daun total }\end{array}$ \\
\hline
\end{tabular}


Pengambilan material (bibit) yang terserang penyakit diperlukan sebagai sumber inokulum untuk identifikasi penyebab penyakit bercak daun nyatoh. Isolasi patogen dilakukan pada media PDA. Uji Postulat Koch dilakukan dengan beberapa cara yaitu menempelkan inokulum patogen yang diambil dari biakan murni ke daun bibit nyatoh yang sehat, dengan cara membuat suspensi patogen yang dioleskan pada daun bibit nyatoh yang terlebih dahulu dilukai dengan ditusuk-tusuk jarum steril, menempelkan langsung daun sakit ke daun sehat. Tanaman yang telah diinokulasi ditutup dengan sungkup plastik untuk menjaga kelembabannya. Pengamatan munculnya gejala dilakukan tiap hari. Gejala yang tampak dibandingkan dengan gejala awal yang ditemukan pada bibit di persemaian. Setelah daun yang sehat menunjukkan gejala serangan bercak daun kemudian melakukan reisolasi.

\section{Di laboratorium}

Material penyakit yang dibawa dari lapangan diidentifikasi yang tahapannya pekerjaannya adalah sebagai berikut :

1. Pembuatan media agar kentang (Potato Dextrose Agar/PDA), $250 \mathrm{~g}$ kentang dikupas dan diiris-iris sebesar dadu $(1 \mathrm{~cm})$, direbus hingga mendidih dan tersisa $1.000 \mathrm{ml}$ air rebusan kentangnya saja. $\mathrm{Ke}$ dalam air rebusan kentang dimasukkan $15 \mathrm{~g}$ agar batang dan $20 \mathrm{~g}$ dektrosa, diaduk hingga merata dan mendidih, media dituang ke dalam labu Erlenmeyer, ditutup kapas dan aluminium foil. Media dalam labu dimasukkan ke dalam otoklaf untuk disterilisasi pada suhu $120^{\circ} \mathrm{C}$ dengan tekanan $15 \mathrm{lb} / \mathrm{in}^{2}$ selama 15 menit (Agrios, 2005). Semua pekerjaan dilakukan secara aseptik.

2. Isolasi patogen dari daun nyatoh dengan menggunakan medium PDA dan dibuat biakan murni. Isolasi diawali dengan penanaman jaringan daun sakit. Jaringan/bagian daun diambil pada perbatasan sehat dan sakit yang dipotong-potong kecil. Potongan didesinfektan dengan alkohol $70 \%$ selama 2 menit, kemudian dipindahkan dalam larutan natrium hipoklorit 3\% selama 2 menit. Potongan kemudian dicuci bersih dengan air steril dan ditiriskan. Potongan daun yang telah kering dipindahkan ke dalam cawan petri berisi PDA. Patogen yang muncul diamati dan dimurnikan dengan cara dipindahkan ke cawan petri lain yang berisi PDA, sampai diperoleh biakan murni. Biakan murni yang didapat diidentifikasi secara makroskopis dan mikroskopis.

3. Pembuatan preparat dengan cara meletakkan jaringan daun yang diiris transparan di atas gelas obyek yang diberi setetes akuades, kemudian ditutup dengan gelas penutup sedemikian rupa agar tidak terjadi gelembung udara. Preparat diamati di bawah mikroskop.

4. Identifikasi patogen, merupakan suatu proses mencocokkan secara umum serta membandingkan ciri-ciri yang terlihat dari pertumbuhan patogen dengan ciri-ciri yang ada pada referensi (Alexopoulos and Mims, 1979; Dwidjoseputro, 1978; Streets, 1980; Agrios, 2005).

5. Patogen yang didapat dari biakan murni dideskripsi secara makroskopis dan mikroskopis dan diuji patogenitasnya (Postulat Koch). Secara makroskopis yang diamati adalah kecepatan pertumbuhan koloni dalam cawan petri dan warna koloni. Pengamatan mikroskopis dengan melihat bentuk patogen yang meliputi bentuk hifa, warna hifa, bentuk spora dan bentuk kotak spora sebagai obyek identifikasi.

\section{HASIL DAN PEMBAHASAN}

\section{A. Gejala}

Ciri dan gejala penyakit daun (bercak daun) pada umumnya sama pada setiap tanaman yaitu terbentuknya daerah yang mati pada daun (nekrosis). Luas daerah nekrosis bervariasi mulai dari yang kecil sampai yang besar, dengan bentuk dari yang tidak beraturan sampai yang beraturan. Begitu pula dengan warna bercak atau daerah nekrosis, beragam mulai dari kuning, coklat hingga hitam. Gejala 
penyakit bercak daun pada bibit nyatoh diawali dengan munculnya bercak-bercak berbentuk agak bulat dengan warna coklat dengan tepi agak kekuning-kuningan, bercak-bercak ini dapat menyatu menjadi bercak yang lebar dalam jangka waktu yang relatif singkat. Bercak yang sudah melebar berwarna coklat merah kehitam-hitaman. Letak bercak pada permukaan daun dimulai dari tepi menuju ke bagian tengah daun. Apabila daun yang terserang disentuh, maka daun tersebut gugur, apabila dibiarkan lama kelamaan daun menjadi kering dan rontok (Gambar 1).

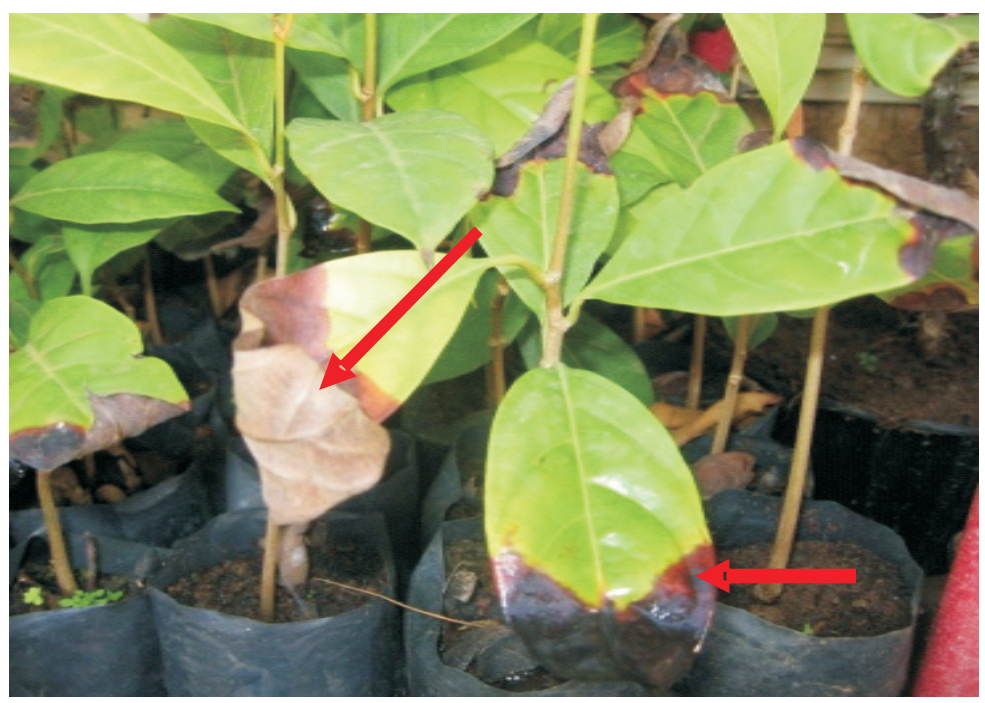

Gambar (Figure) 1. Gejala bercak daun pada bibit nyatoh (Leaf spot symptom on nyatoh seedlings)

\section{B. Identifikasi Patogen}

Hasil isolasi dari daun nyatoh pada medium PDA menunjukkan bahwa jenis patogen yang menyebabkan penyakit bercak daun adalah jenis fungi. Setelah daun nyatoh diisolasi selama tiga hari baru tampak hifa berwarna putih seperti kapas yang mengelilingi potongan daun. Pada umur 4 hari, hifa semakin menebal dan tetap berwarna putih. Setelah umur 5 hari koloni mulai berwarna keabu-abuan dan pada umur 8 hari koloni berwarna abu-abu tua kehitam-hitaman. Dari koloni fungi dibuat preparat mikroskopik untuk mengetahui bentuk hifa dan konidia fungi. Hasil pengamatan secara mikroskopis menunjukkan bahwa fungi tersebut mempunyai hifa yang bersekat, menghasilkan konidia yang sangat banyak berbentuk silindris dan ada pula konidia berbentuk silindris, konidia bersel tunggal, tidak bersekat berwarna hialin berbercak-bercak. Konidia terbentuk di ujung konidiofor yang tidak bersekat dan tidak bercabang (Gambar 2).

Street (1980) menyatakan bahwa untuk melakukan identifikasi fungi yang menyebabkan penyakit tanaman diperlukan dua macam informasi, yaitu makroskopis, yang mencakup gejala-gejala yang timbul pada tanaman inang dan pertumbuhan miselium atau tubuh buah yang diamati dengan mata langsung atau dengan bantuan lensa tangan; dan mikroskopis untuk menentukan sifat-sifat khas (diagnostik) yang dapat mencirikan jenis fungi dengan menggunakan mikroskop.

Dari hasil reisolasi diperoleh isolat yang identik dengan hasil isolasi. Hal ini menunjukkan bahwa fungi yang diperoleh pada tahap isolasi dan reisolasi merupakan patogen penyebab penyakit primer pada daun bibit nyatoh ( hasil ini sesuai dengan tahapan Postulat Koch).

Berdasarkan penampilan secara makroskopis yang mencakup gejala-gejala yang timbul pada bibit nyatoh dan pertumbuhan koloni pada media PDA, pengamatan mikroskopis dengan cara pembuatan preparat basah (langsung dari daun yang sakit) dan dari preparat biakan murni dengan berbagai perbesaran, serta hasil inokulasi (Postulat Koch), dapat disimpulkan bahwa fungi ini termasuk dalam 
kelas Deuteromycetes. Dwidjoseputro (1978) menyebutkan bahwa fungi ini memiliki hifa yang bersekat-sekat dan menghasilkan konidia, akan tetapi fungi tersebut tidak atau belum diketahui cara pembiakan generatifnya, sehingga dikelompokkan dalam kelas khusus yaitu Deuteromycetes atau fungi imperfect (jamur tak sempurna).
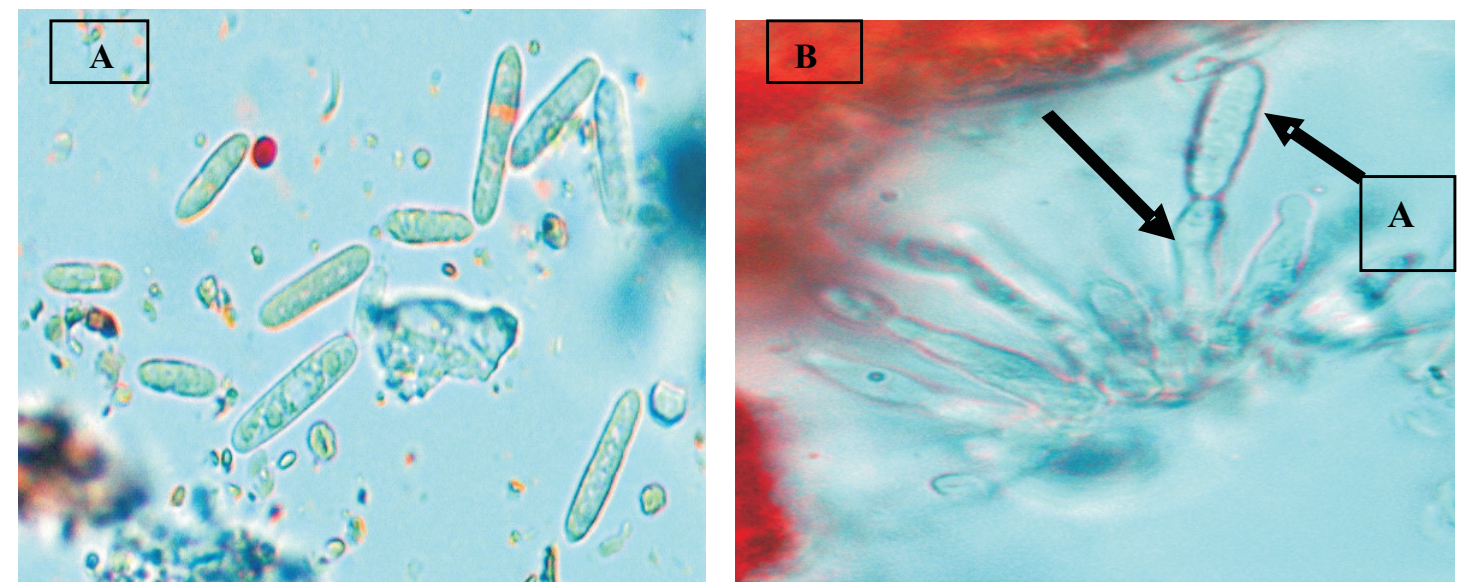

Gambar(Figure) 2. A. konidia (Conidia), B. konidiofor dari fungi penyebab penyakit bercak daun (Conidiophores of fungi causing leaf spot disease)
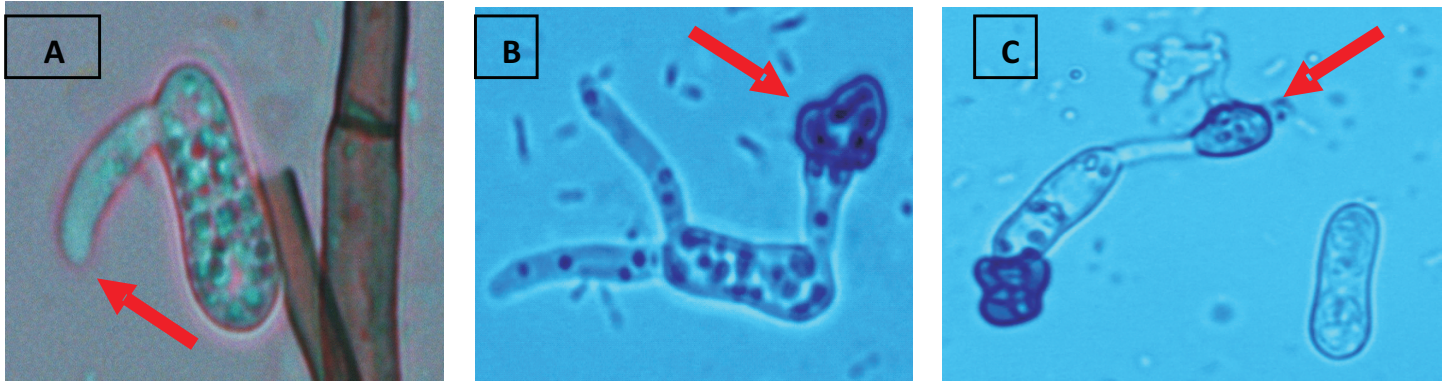

Gambar(Figure)3. A. Konidia berkecambah (Germinating conidia), B dan C. Apresoria dari fungi penyebab penyakit bercak daun (Appressorium of fungi causing leaf spot disease)

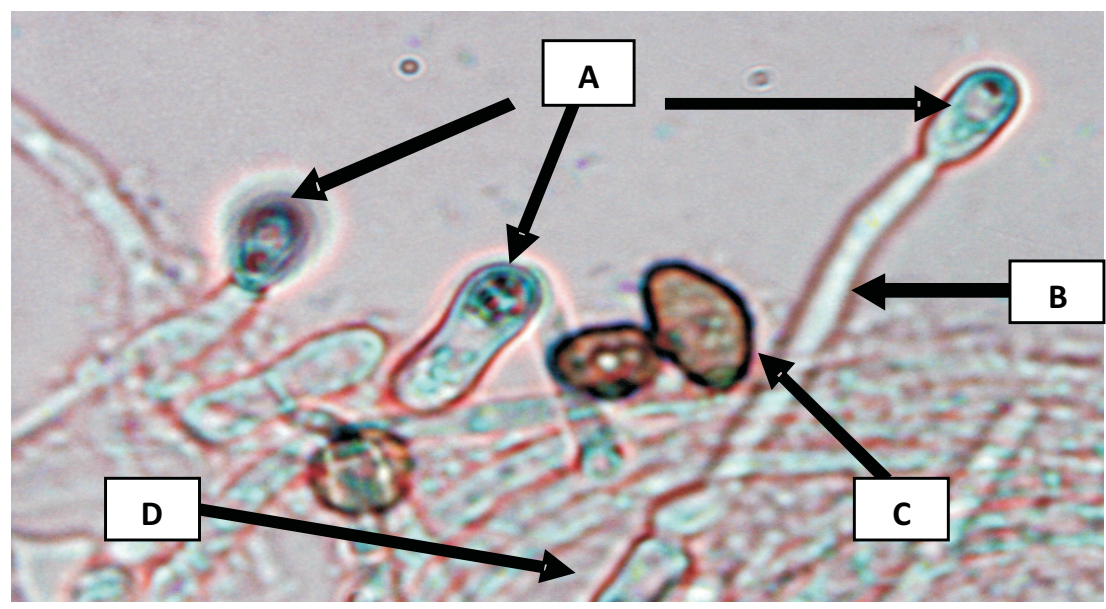

Gambar(Figure) 4. A. Konidia (Conidia), B. Konidiofor (Conidiophore), C. Apresoria (Appressorium), D. Epidermis daun (Epidermis). 
Tjitrosomo (1986) melaporkan bahwa sebagian besar fungi yang tergolong fungi imperfect mempunyai hifa septat. Konidium biasanya dibentuk dari sel-sel konidiogen. Konidiofor merupakan hifa sederhana atau bercabang yang berasal dari hifa somatik dan menghasilkan satu atau lebih sel-sel konidiogen. Konidiofor dapat dibentuk melalui dua cara yaitu pertama tidak di dalam tubuh buah, tetapi berkelompok membentuk struktur khusus yaitu sinema dan sporodokium dan kedua di dalam tubuh buah yang disebut piknidium dan aservulus. Berikut ini disajikan klasifikasi Deuteromycetes (Tjitrosomo, 1986) : 1). Form-subkelas Coelomycetidae, pada form ini konidia dibentuk di dalam piknidia atau aservulus. Jenis yang membentuk piknidia digolongkan ke dalam form-ordo Sphaeropsidales, sedangkan yang membentuk aservuli digolongkan ke dalam form-ordo Melanconiales. 2). Form-subkelas Hypomycetidae, pada form ini konidiofor dan konidiumnya berwarna gelap. Sebagian besar hidupnya secara saprobik, beberapa sebagai parasit.

Berdasarkan pengamatan makroskopis dan mikroskopis tersebut diatas, hasil identifikasi dan deskripsi dengan pustaka dari Alexopoulos and Mims (1979), Dwidjoseputro (1978) dan Streets (1980), diketahui bahwa fungi penyebab penyakit bercak daun pada bibit nyatoh adalah dari genus Colletotrichum. Secara lengkap klasifikasi fungi patogen bercak daun pada bibit nyatoh menurut Alexopoulos dan Mims (1979) adalah sebagai berikut:
Divisio
Amastigomycota
Subdivisio
Deuteromycotina
Form-kelas
Deuteromycetes
Form-subkkelas
Coelomycetidae
Form-ordo
Melanconiales
Form-famili
Melanconiaceae
Form-Genus
Colletotrichum

Colletotrichum sp. mempunyai beberapa sinonim tergantung dari spesiesnya, tingkat seksual dari fungi ini juga sudah diketahui yaitu Glomerella sp. yang masuk ke dalam kelas Ascomycetes, ordo Diaporthales, dan famili Diaporthaceae (Dwidjoseputro, 1976). Colletotrichum sp. membentuk banyak aservulus berbentuk bulat setengah bulat atau lonjong, berwarna gelap. Banyak spesies dari famili Melanconiales merupakan parasit, menyebabkan penyakit tumbuhan yang terkenal sebagai penyakit antraknosa. Menurut Agrios (2005) antraknosa berarti Anthrax = carbon = black, artinya penyakit antraknosa disebabkan oleh jenis fungi yang menghasilkan konidia dalam aservulus berwarna hitam. Penyakit antraknosa dilaporkan menyerang berbagai tanaman pertanian seperti cabe, alpukat, jeruk, kacang kedelai, strawberi, pepaya, mangga, dll. (Agrios, 2005); menyerang tanaman perkebunan seperti kopi dan karet (Agrios, 2005; Semangun, 2000); Tanaman kehutanan seperti Acacia spp. (Old et al., 2000), jabon, pulai, tembesu, jati, cendana, tanjung (Anggraeni, 2008). Penyakit antraknosa menyerang berbagai bagian dari tanaman seperti buah, batang dan daun, menyerang tanaman pada berbagai umur mulai dari pembibitan yang terbawa benih sampai tanaman di lapangan. Colletotrichum sp. merupakan patogen akar yang dapat bertahan hidup tanpa adanya tanaman inang, dengan cara hidup sebagai saprofit pada jaringan mati dengan membentuk struktur istirahat dan pada fase parasitik menginfeksi gulam atau tanaman inang. Selama hidup secara saprofitik, mengkolonisasi substrat organik, atau hidup secara parasitik pada akar tanaman dengan tidak memperlihatkan gejala sakit (Garrett, 1970).

Perkembangan penyakit tergantung pada lingkungan, kondisi yang sesuai untuk perkembangan penyakit antraknosa adalah pada kelembaban relatif (RH) 95\% - 100\%. Suhu optimum untuk perkembangan Colletotrichum sp. adalah $28^{\circ} \mathrm{C}-36^{\circ} \mathrm{C}$. Hal ini menyebabkan serangan penyakit di musim penghujan lebih tinggi daripada di musim kemarau Konidia biasanya membentuk satu atau dua tabung kecambah. Bila tabung kecambah mengenai permukaan benda padat maka terbentuklah apresorium berwarna gelap/hitam dan lengket, dan fungi dapat langsung menembus kutikula daun. Fungi masuk ke dalam tanaman inang melalui lubang alami (stomata), melalui luka dan penetrasi langsung pada kutikula. Agrios (2005) menggambarkan siklus hidup penyakit antraknosa pada berbagai tanaman pertanian (Gambar 5). 


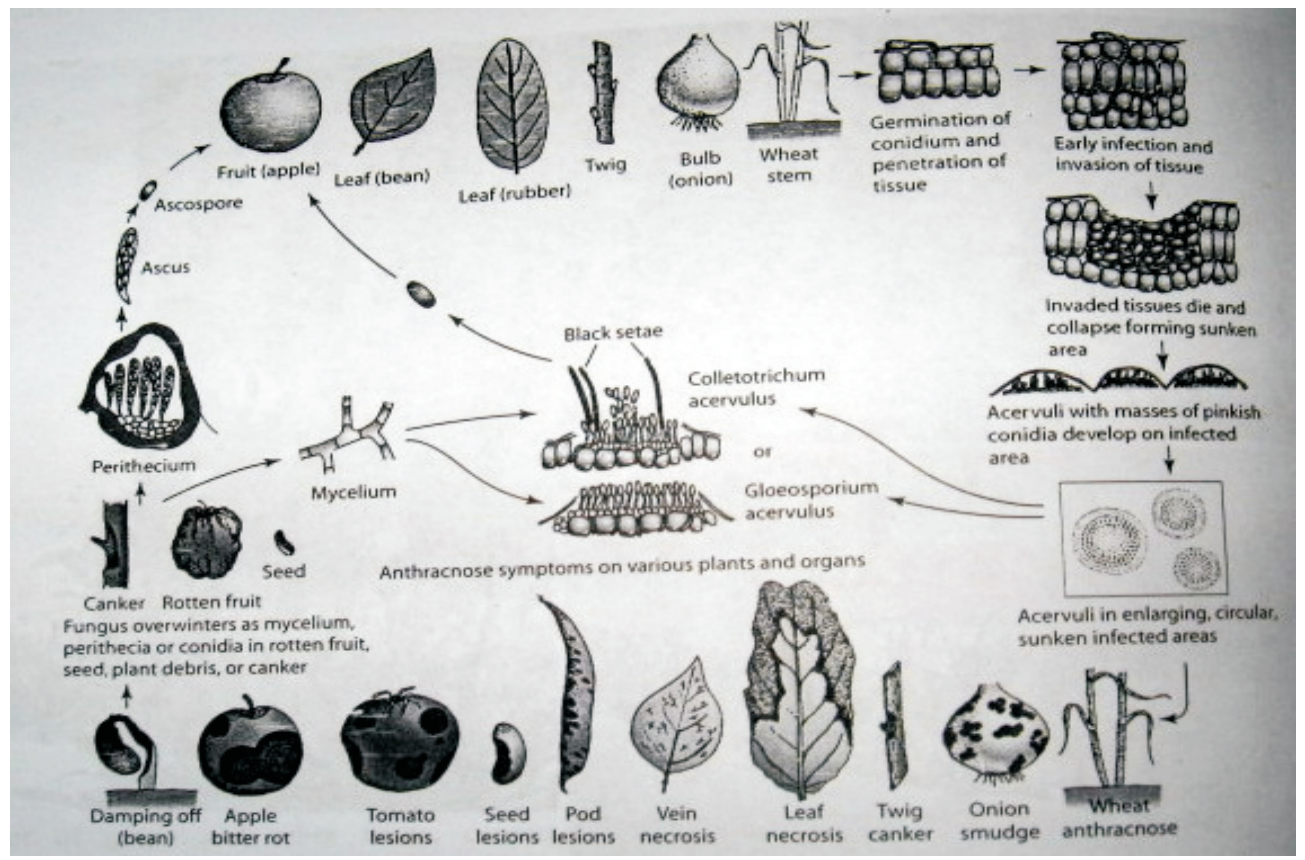

Gambar(Figure) 5. Siklus hidup penyakit antraknosa yang disebabkan Colletotrichum sp. pada berbagai tanaman (Disease cycle of antracnose caused by Colletotrichum sp. on plants) (Agrios, 2005).

\section{Persentase Kejadian Penyakit dan Intensitas Serangan Penyakit}

Rata-rata persentase dan intensitas serangan bercak daun pada bibit nyatoh terdapat pada Tabel 2.

Tabel(Table)2. Rata-rata persentase dan intensitas serangan bercak daun pada bibit nyatoh (Average of percentage and intensity of leaf spot disease attack on nyatoh seedlings)

\begin{tabular}{|c|c|c|c|c|c|}
\hline \multicolumn{2}{|c|}{$\begin{array}{c}\text { Rata-rata Persentase Serangan Penyakit (Average of } \\
\text { percentage disease attack) } \\
(\%)\end{array}$} & \multicolumn{3}{|c|}{$\begin{array}{c}\text { Rata-rata Intensitas Serangan Penyakit } \\
\text { (Average of intensity disease attack) } \\
(\%)\end{array}$} \\
\hline Plot I & Plot II & Plot III & Plot I & Plot II & Plot III \\
\hline 96 & 96 & 100 & 24,60 & 28,87 & 31,45 \\
\hline
\end{tabular}

Intensitas serangan penyakit bercak daun Colletotrichum sp. pada bibit nyatoh bervariasi berkisar $24,60 \%-31,45 \%$ dengan persentase serangan berkisar $96 \%-100 \%$. Hal tersebut menunjukkan bahwa bibit nyatoh mempunyai respon rentan terhadap penyakit bercak daun Colletotrichum sp., apalagi dengan lingkungan yang mendukung. Perkembangan penyakit sangat dibantu oleh kelembaban udara dan hujan. Pada cuaca yang sangat lembab fungi membentuk spora dalam jumlah banyak.

Beberapa patogen memang menyenangi anakan semai karena lebih sukulen, jaringan relatif kurang berserat dan berlignin, serta kemampuan adaptasinya masih rendah. Rentanitas anakan semai terhadap serangan penyakit lebih tinggi dibandingkan dengan tanaman dewasa, karena kondisi fisiologinya yang sangat lemah dan rapuh. Baker (1950) memberikan dua gambaran kondisi fisiologis tanaman sebelum mencapai pertumbuhan yang mantap, yaitu :

- Tingkat sukulen, hanya berlangsung beberapa minggu saja, mulai dari saat munculnya benih di atas permukaan tanah hingga hipokotil mengeras. 
- Tingkat juvenil, mulai mengerasnya hipokotil hingga periode yang tidak tertentu, sangat tergantung pada kondisi lingkungan anakan tersebut.

Pengukuran persentase kejadian penyakit (luas serangan penyakit) dan intensitas serangan penyakit bercak daun pada bibit nyatoh dilakukan untuk mengukur perkembangan epidemik dan mengetahui faktor-faktor yang mempengaruhi perkembangan penyakit. Penyakit epidemik adalah meningkatnya penyakit dengan hebat pada waktu dan wilayah tertentu dalam satu populasi tumbuhan (Semangun, 1996). Penyakit endemik juga menggambarkan suatu penyakit yang terbatas pada wilayah geografis tertentu atau penyakit yang selalu terdapat di daerah tertentu dengan menimbulkan kerugian ringan sampai berat. Beratnya penyakit yang infeksius ditentukan oleh berbagai variabel yaitu : 1) Ketahanan tanaman; 2) Jumlah patogen; 3) Virulensi patogen; 4) Kesesuaian keadaan lingkungan terhadap perkembangan patogen; 5) Lamanya keadaan yang sesuai untuk patogen. Dengan demikian timbulnya peledakan (outbreak) penyakit secara luas tergantung dari : 1) Banyaknya tanaman rentan; 2) Banyaknya patogen yang virulen; 3) Keadaan lingkungan yang sesuai untuk patogen dalam jangka waktu lama.

Akibat serangan penyakit bercak daun memang belum terasa artinya tetapi apabila hal ini dibiarkan maka penyakit akan terus berkembang dan membahayakan tanaman terutama bibit, karena bibit mempunyai kerentanan yang tinggi terhadap serangan penyakit. Kerusakan pada daun menyebabkan proses fotosintesa yang sangat penting dalam pertumbuhan terganggu dan pada tingkat persemaian hal ini dapat menimbulkan kerugian yang cukup berarti karena dapat mengakibatkan gugurnya daun yang pada akhirnya mengakibatkan kematian tanaman.

\section{KESIMPULAN}

1. Penyakit bercak daun pada bibit nyatoh disebabkan oleh fungi patogen Colletotrichum sp. yang termasuk famili Melanconiaceae.

2. Persentase kejadian penyakit berkisar antara 96\% sampai dengan $100 \%$. Sedangkan rata-rata intensitas serangan berkisar antara $24,60 \%$ sampai dengan $31,45 \%$.

\section{DAFTAR PUSTAKA}

Agrios, G.N. 2005. Plant Pathology. $5^{\text {th }}$ Edition. Elsevier Academic Press, USA.

Alexopoulos, C.J. dan C.W. Mims. 1979. Introductory Mycology. John Wiley \& Sons.

Anggraeni, 1. 2008. Identifikasi Mikroskopis Penyakit Bercak Daun Jabon, Pulai, Tembesu, Jati, Cendana dan Tanjung. Tidak dipublikasikan.

Anonim. 1991. Uji Coba Pengembangan Tanaman Nyatoh (Palaquium sp.) di Benakat. Balai Teknologi Reboisasi Benakat.

Baker, F.E. 1950. Principles of Silviculture. McGraw-Hill Book Company, Inc, New York.

Dwidjoseputro. D. 1978. Pengantar Mikologi. Penerbit Alumni, Bandung.

Garrett, S.D. 1970. Pathogenic Root-Infecting Fungi. Cambridge at University Press, Cambridge.

Martawijaya, A., L. Kartasujana, K. Kadir dan S. A. Prawira. 2005. Atlas Kayu Indonesia. Jilid I. Badan Penelitian dan Pengembangan Kehutanan, Jakarta.

Old, K.M., L.S. See, J.K. Sharma, dan Z.Q. Yuan. 2000. A Manual of Diseases of Tropical Acacias in Australia, South-East Asia and India. Center for International Forestry Research (CIFOR), Jakarta. 
Schmidt, F.H. dan J.H.A. Ferguson. 1951. Rainfall Types Based on Wet and Dry Period Ratios for Indonesia With Western New Guinea. Verh. No. 42. Direktorat Meteorologi dan Geofisika, Jakarta.

Semangun H. 2000. Penyakit-Penyakit Tanaman Perkebunan di Indonesia. Gadjah Mada University Press, Yogyakarta.

Sinaga, M.S. 2000. Diktat Kuliah Dasar-dasar Ilmu Penyakit Tumbuhan. Fakultas Pertanian IPB, Bogor.

Streets, R.B. 1980. Diagnosis Penyakit Tanaman (Terjemahan: Imam Santoso). The University of Arizona Press, Tuscon, Arizona, USA

Tjitrosomo, S.S. 1987. Botani Umum IL Penerbit Angkasa, Bandung 